\title{
EKSPERIMENTASI MODEL PEMBELAJARAN KOOPERATIF TIPE JIGSAW YANG DIMODIFIKASI DITINJAU DARI GAYA KOGNITIF SISWA KELAS VIII SMP NEGERI DI KABUPATEN GROBOGAN TAHUN 2010/2011
}

\author{
Moertiningsih E.P.U, Riyadi, Budi Usodo
}

\begin{abstract}
ABSTRAK
Tujuan penelitian ini adalah untuk mengetahui: (1) Apakah pembelajaran matematika dengan menggunakan model pembelajaran kooperatif tipe Jigsaw yang dimodifikasi memberikan prestasi yang lebih baik dibandingkan dengan model pembelajaran kooperatif tipe Jigsaw, dan keduanya lebih baik daripada pembelajaran konvensional. (2) Apakah siswa dengan gaya kognitif field independent mempunyai prestasi belajar matematika yang lebih baik daripada siswa dengan gaya kognitif field dependent. (3) Apakah penerapan model pembelajaran kooperatif tipe Jigsaw yang dimodifikasi memberikan prestasi yang lebih baik daripada model pembelajaran kooperatif tipe Jigsaw dan pembelajaran konvensional pada siswa dengan gaya kognitif field dependent maupun field independent.

Penelitian ini merupakan penelitian eksperimental semu dengan desain eksperimen $3 \times 2$. Populasi penelitian ini adalah seluruh siswa kelas VIII (delapan) SMP Negeri di Grobogan semester dua tahun pelajaran 2010/2011. Pengambilan sampel dilakukan dengan stratified cluster random sampling. Sampel dalam penelitian ini berasal dari SMP Negeri 1 Purwodadi, SMP Negeri 2 Grobogan, dan SMP Negeri 6 Purwodadi yang berjumlah 307 siswa. Instrumen yang digunakan untuk mengumpulkan data adalah tes prestasi belajar matematika dan tes gaya kognitif siswa. Uji instrumen meliputi validitas isi instrumen tes dilakukan oleh validator dan uji reliabilitas instrumen tes menggunakan rumus KR-20. Uji keseimbangan menggunakan uji anava satu jalan dengan sel tak sama. Uji prasyarat meliputi uji normalitas dengan menggunakan metode uji Lilliefors dan uji homogenitas menggunakan metode Bartlett dengan statistik uji Chi Kuadrat. Uji hipotesis menggunakan uji anava 2 jalan dengan sel tak sama.

Hasil analisis data dengan anava dua jalan sel tak sama menunjukkan (1) Terdapat perbedaan rataan antara model pembelajaran kooperatif tipe Jigsaw yang dimodifikasi, tipe Jigsaw dan konvensional terhadap prestasi belajar matematika $\left(\mathrm{F}_{\mathrm{a}}=26,749>\mathrm{F}_{0,05 ; 2 ; 301}=3,026\right)$. (2) Terdapat pengaruh yang signifikan gaya kognitif siswa terhadap prestasi belajar matematika $\left(\mathrm{F}_{\mathrm{b}}=22,652>\mathrm{F}_{0,05 ; 1 ; 301}=3,026\right)$. (3) Tidak terdapat interaksi antara model pembelajaran dengan gaya kognitif terhadap prestasi belajar matematika $\left(\mathrm{F}_{\mathrm{ab}}=1,618<\mathrm{F}_{0,05 ; 2 ; 301}=3,026\right)$.

Berdasarkan uji hipotesis dan uji pasca anava diperoleh kesimpulan bahwa: (1) Pembelajaran matematika dengan menggunakan model pembelajaran kooperatif tipe Jigsaw yang dimodifikasi menghasilkan prestasi belajar yang lebih baik dibandingkan dengan pembelajaran kooperatif tipe Jigsaw, dan keduanya menghasilkan prestasi belajar yang lebih baik dibandingkan dengan menggunakan pembelajaran konvensional. (2) Siswa dengan gaya kognitif field independent mempunyai prestasi belajar lebih baik daripada siswa dengan gaya kognitif field dependent. (3) Pada siswa dengan gaya kognitif field independent maupun field dependent yang diberikan model pembelajaran kooperatif tipe Jigsaw yang dimodifikasi mempunyai prestasi belajar lebih baik dibandingkan dengan model pembelajaran kooperatif tipe Jigsaw dan keduanya lebih baik daripada pembelajaran konvensional.
\end{abstract}

Kata kunci: Jigsaw yang dimodifikasi, Jigsaw, Gaya Kognitif, Field Independent, Field Dependent.

\section{PENDAHULUAN}

Salah satu materi matematika yang penguasaan siswa rendah di Kabupaten Grobogan adalah pada pokok bahasan bangun ruang sisi datar, di mana pada materi tersebut banyak siswa yang belum dapat menentukan banyak rusuk pada prisma/limas segi $\mathrm{n}$, siswa juga kurang bisa menyelesaikan soal yang berkaitan dengan luas permukaan bangun ruang sisi datar. Hal ini dapat dilihat dari data Pusat Penilaian Pendidikan Balitbang, Depdiknas, (2009) tentang hasil UN SMP/MTs tahun pelajaran 2008/2009 yang menunjukkan bahwa persentase penguasaan materi soal matematika untuk kemampuan menentukan banyak rusuk pada prisma/limas segi n, mencapai 53,72, dan data Pusat Penilaian 
Pendidikan - Balitbang, Depdiknas, (2010) tentang hasil UN tingkat SMP/MTs tahun pelajaran 2009/2010 untuk kemampuan menyelesaikan soal yang berkaitan dengan luas permukaan bangun ruang sisi datar, persentase penguasaan materi mencapai 46,92. Berbagai data tersebut dapat memberikan gambaran kepada penulis bahwa prestasi belajar siswa untuk materi bangun ruang sisi datar masih sangat kurang

Dalam paradigma baru tentang pembelajaran, siswa dituntut untuk mengkonstruksi pengetahuan dan pengalaman yang diperolehnya sehingga bermakna bagi dirinya. Menurut Jean Piaget (dalam Riyanto, 2009:9) Pengetahuan dibangun dalam pikiran anak melalui proses asimilasi dan akomodasi. Asimilasi adalah penyerapan informasi baru ke dalam pikiran, sedangkan akomodasi adalah penyusunan kembali struktur pikiran karena adanya informasi baru. Artinya, siswa seharusnya membangun pemahaman sendiri tentang konsep atau struktur dari materi yang dipelajarinya, tidak diberitahukan langsung oleh guru.

Namun pada kenyataan di lapangan, masih sering ditemukan pembelajaran dimana siswa hanya menerima paket-paket pengetahuan yang diberikan langsung oleh guru. Seperti yang diungkapkan oleh Wahyudin (Shofiah, 2007 : 4) bahwa pilihan favorit guru dalam mengajar matematika adalah metode ceramah, guru asyik mencatat di depan kelas dan siswa mencatat, kemudian siswa disuruh mengerjakan latihan dan diberi pekerjaan rumah.

Untuk mendapatkan hasil dari proses pendidikan yang maksimal perlu pemikiran yang kreatif dan inovatif. Inovasi dalam proses pembelajaran sangat diperlukan guna meningkatkan prestasi ke arah yang maksimal. Inovasi ini dapat dilakukan dengan menggunakan beberapa pendekatan pembelajaran, strategi pembelajaran, dan metode pembelajaran. Dalam mengajar sebuah konsep, guru dapat mencari cara yang menarik agar anak didik berminat, bersemangat dan termotivasi dalam mempelajari matematika. Salah satu cara meningkatkan prestasi belajar adalah dengan menerapkan model pembelajaran yang menarik. Model pembelajaran yang menarik adalah model yang dapat meningkatkan keaktifan dan kreativitas siswa dalam belajar. Model pembelajaran yang menarik adalah mengembangkan model pembelajaran yang pernah digunakan dan sudah ada sebelumnya. Model pembelajaran konvensional yang digunakan oleh sebagian besar guru tidak sesuai dengan tuntutan jaman, karena pembelajaran yang dilakukan kurang memberikan kesempatan seluas-luasnya bagi siswa untuk aktif mengkonstruksi pengetahuannya.

Salah satu model pembelajaran yang dimungkinkan mampu mengantisipasi kelemahan model pembelajaran konvensional adalah dengan menggunakan model pembelajaran kooperatif tipe Jigsaw. Pembelajaran model ini lebih meningkatkan kerja sama antar siswa. Kelas dibagi menjadi kelompok-kelompok belajar yang terdiri dari siswa-siswa yang bekerja sama dalam suatu perencanaan kegiatan. Dalam pembelajaran ini setiap anggota kelompok diharapkan dapat bekerja sama dan bertanggung jawab baik kepada dirinya sendiri maupun pada kelompoknya. 
Salah satu karakteristik siswa yang mempengaruhi hasil belajar, khususnya pembelajaran matematika adalah gaya kognitif, yang dibedakan berdasarkan perbedaan psikologis yaitu: gaya kognitif field independent dan field dependent. Menurut Keefe (1987: 7), gaya kognitif merupakan bagian gaya belajar yang menggambarkan kebiasaan berperilaku yang tetap dalam diri seseorang dalam menerima, memikirkan, memecahkan masalah maupun dalam menyimpan informasi. Seorang yang memiliki gaya kognitif field independent cenderung kurang begitu tertarik dengan fenomena sosial dan lebih suka dengan ide-ide dan prinsip-prinsip yang abstrak, kurang hangat dalam hubungan interpersonal, dalam mengerjakan tugasnya merasa efisien bekerja sendiri. Orang yang memiliki gaya kognitif field dependent dikategorikan sebagai seorang yang dapat berpikir secara global, berperilaku sensitif secara sosial dan berorientasi interpersonal, lebih suka bekerja kelompok dalam mengerjakan tugasnya.

\section{MODEL PEMBELAJARAN KOOPERATIF TIPE JIGSAW}

\section{Jigsaw 1}

Teknik mengajar Jigsaw I dikembangkan oleh Aronson sebagai model Cooperative Learning. Model pembelajaran kooperatif tipe Jigsaw I merupakan model pembelajaran kooperatif, siswa belajar dalam kelompok kecil yang terdiri dari $4-5$ orang dengan memperhatikan keheterogenan, bekerjasama positif dan setiap anggota bertanggung jawab untuk mempelajari masalah tertentu dari materi yang diberikan dan menyampaikan materi tersebut kepada anggota kelompok yang lain.

Qiao Mengduo dan Jin Xiaoling mengemukakan bahwa:

"In the original jigsaw, each member of a group was assigned a different part of material. Then all the students from different groups who had the same learning material gathered together and formed an "expert group" to discuss and communicate with each other until they all mastered the material. Later, the students returned back to their home group to teach the material to other members of their group."

Para anggota dari tim-tim yang berbeda, tetapi membicarakan topik yang sama disebut expert group (kelompok ahli) bertemu untuk belajar dan saling membantu dalam mempelajari topik tersebut. Setelah itu siswa kembali ke tim asalnya dan mengajarkan sesuatu yang telah mereka pelajari dalam expert group kepada anggota-anggota lain di timnya masing-masing. Setelah pertemuan dan diskusi tim asal, siswa mengerjakan kuis secara individual tentang berbagai materi belajar.

\section{Jigsaw 2}

Jigsaw II adalah bentuk adaptasi dari Jigsaw yang lebih praktis dan mudah (Slavin, 2008:237). Dan model pembelajaran kooperatif yang penulis gunakan dalam penelitian ini adalah model pembelajaran kooperatif tipe Jigsaw II. 
Dalam model pembelajaran kooperatif tipe Jigsaw II, para siswa bekerja dalam tim yang heterogen dan terdapat kelompok ahli dan kelompok asal. Kelompok asal adalah kelompok awal siswa terdiri dari berapa anggota kelompok ahli yang dibentuk dengan memperhatikan keragaman dan latar belakang. Guru harus terampil dan mengetahui latar belakang siswa agar terciptanya suasana yang baik bagi setiap angota kelompok. Sedangkan kelompok ahli, yaitu kelompok siswa yang terdiri dari anggota kelompok lain (kelompok asal) yang ditugaskan untuk mendalami topik tertentu untuk kemudian dijelaskan kepada anggota kelompok asal.

Para anggota dari kelompok asal yang berbeda, bertemu dengan topik yang sama dalam kelompok ahli untuk berdiskusi dan membahas materi yang ditugaskan pada masing-masing anggota kelompok serta membantu satu sama lain untuk mempelajari topik mereka tersebut. Di sini, peran guru adalah memfasilitasi dan memotivasi para anggota kelompok ahli agar mudah untuk memahami materi yang diberikan. Setelah pembahasan selesai, para anggota kelompok kemudian kembali pada kelompok asal dan mengajarkan pada teman sekelompoknya apa yang telah mereka dapatkan pada saat pertemuan di kelompok ahli. Para kelompok ahli harus mampu untuk membagi pengetahuan yang di dapatkan saat melakukan diskusi di kelompok ahli, sehingga pengetahuan tersebut diterima oleh setiap anggota pada kelompok asal.

Langkah yang terakhir adalah para siswa menerima penilaian yang mencakup seluruh topik dan skor kuis akan menjadi skor tim. Kemudian, skor-skor yang dikontribusikan para siswa kepada timnya didasarkan pada sistem skor perkembangan individual dan para siswa yang timnya meraih skor tertinggi akan menerima sertifikat atau bentuk-bentuk rekognisi tim lainnya. Sehingga, para siswa termotivasi untuk mempelajari materi dengan baik dan untuk bekerja keras dalam kelompok ahli mereka supaya mereka dapat membantu timnya melakukan tugas dengan baik. Seperti yang dikemukakan oleh Chan Kam-wing, the implementation of Jigsaw II comprises five steps: (1) reading; (2) expert group discussion; (3) home group reporting; (4) testing; and (5) group recognition.

\section{TIPE JIGSAW YANG DIMODIFIKASI}

Pengembangan model pembelajaran tipe Jigsaw tetap berdasar pada tipe Jigsaw yang sudah ada. Pada penelitian ini penulis akan memodifikasi tipe Jigsaw ini dengan langkahlangkah sebagai berikut:

a. Guru membagi suatu kelas menjadi beberapa kelompok, dengan setiap kelompok terdiri dari 4-6 siswa dengan kemampuan yang berbeda, ada siswa yang mempunyai kemampuan tinggi, sedang dan rendah yang disebut kelompok asal. Pengelompokan dilakukan dengan terlebih dahulu mengurutkan kemampuan matematika siswa dalam kelas. Sebagai contoh, dalam kelas terdiri dari 24 orang siswa, karena pada materi bangun ruang sisi datar terdiri dari 4 sub topik, maka penulis membaginya menjadi enam kelompok yang masing-masing kelompok terdiri dari 4 siswa. 
Cara membagi kelompok diantaranya adalah: 25\% (rangking 1-6) kelompok sangat baik, 25\% (rangking 7-12) kelompok baik, 25\% (rangking 13-18) kelompok sedang, dan 25\% (rangking 19-24) kelompok rendah. Selanjutnya dibagi menjadi 6 kelompok (A F) yang tiap-tiap kelompoknya heterogen dalam kemampuan matematika. Beri indeks 1 untuk siswa berkemampuan sangat baik, indeks 2 untuk siswa berkemampuan baik, indeks 3 untuk siswa berkemampuan sedang dan indeks 4 untuk siswa bekemampuan rendah. Misal, $\mathrm{A}_{1}$ berarti kelompok A dari siswa berkemampuan sangat baik, $A_{3}$ berarti kelompok A dari siswa berkemampuan sedang. Tiap kelompok akan diisi oleh siswa berkemampuan sangat baik, baik, sedang dan rendah, misal kelompok $A$ terdiri dari $\left\{\mathrm{A}_{1}, \mathrm{~A}_{2}\right.$, $\left.\mathrm{A}_{3}, \mathrm{~A}_{4}\right\}$, kelompok $\mathrm{B}$ terdiri dari $\left(\mathrm{B}_{1}, \mathrm{~B}_{2}, \mathrm{~B}_{3}\right.$, $\left.\mathrm{B}_{4}\right\}$ dan seterusnya.

b. Menempatkan siswa ke dalam kelompok ahli dan menjamin bahwa masing-masing siswa ahli dan kompeten dibidangnya. Dan untuk menjamin bahwa siswa ahli dan kompeten dibidangnya, penulis memodifikasinya dengan terlebih dahulu memberikan pre-tes pada masing-masing kelompok. Soal tes terdiri dari 4 soal yang berisi soal pada topik 1, topik 2 , topik 3 dan topik 4. Setelah dikoreksi, kemudian siswa dibagi dalam kelompok ahli sesuai dengan perolehan nilai individu pada masing-masing kelompok.

Langkah pertama yang diambil adalah dengan menempatkan terlebih dahulu siswa berkemampuan rendah dengan perolehan nilai tertinggi, kemudian pada siswa yang berkemampuan sedang dengan perolehan nilai tertinggi yang tidak ditempati oleh siswa berkemampuan rendah dan yang terakhir penempatan siswa yang berkemampuan tinggi. Siswa yang berkemampuan tinggi ditempatkan terakhir karena siswa ini dianggap mampu untuk memahami semua materi yang dipelajari.

Contoh pembagian siswa ke dalam kelompok ahli (kelompok A) adalah sebagai berikut:

Tabel 1. Pembagian siswa dalam kelompok ahli

\begin{tabular}{|l|l|l|l|l|l|}
\hline \multirow{2}{*}{ Siswa } & \multicolumn{4}{|l|}{ Nomor soal } & \multirow{2}{*}{ Ahli } \\
\cline { 2 - 5 } & 1 & 2 & 3 & 4 & \\
\hline $\mathrm{A}_{1}$ & 90 & 85 & 90 & 90 & 4 \\
\hline $\mathrm{A}_{2}$ & 85 & 85 & 80 & 80 & 2 \\
\hline $\mathrm{A}_{3}$ & 75 & 70 & 75 & 70 & 3 \\
\hline $\mathrm{A}_{4}$ & 65 & 50 & 60 & 60 & 1 \\
\hline
\end{tabular}

Langkah-langkah:

1) Mulailah pengelompokan dari siswa berkemampuan rendah $\left(\mathrm{A}_{4}\right)$. Nilai tertinggi dari siswa $\mathrm{A}_{4}$ adalah 65 pada soal nomor 1, berarti siswa $\mathrm{A}_{4}$ ditempatkan pada kelompok ahli dengan topik 1 .

2) Kemudian pada siswa $A_{3}$, nilai tertinggi pada siswa $\mathrm{A}_{3}$ adalah 75 pada soal nomor 1 
dan 3 yang seharusnya ditempatkan pada kelompok ahli dengan topik 1 atau 3 . Karena kelompok ahli dengan topik 1 sudah ditempati oleh $\mathrm{A}_{4}$, maka $\mathrm{A}_{3}$ ditempatkan pada ahli dengan topik 3 .

3) Selanjutnya pada siswa $A_{2}$, nilai tertinggi dari siswa $\mathrm{A}_{2}$ adalah 85 pada soal nomor 1 dan 2 yang seharusnya ditempatkan pada kelompok ahli dengan topik 1 atau 2 . Karena kelompok ahli 1 sudah ditempati oleh $\mathrm{A}_{4}$, maka siswa $\mathrm{A}_{2}$ ditempatkan pada kelompok ahli dengan topik 2.

4) Yang terakhir adalah menempatkan siswa $A_{1}$. Siswa $A_{1}$ ditempatkan pada kelompok ahli yang belum ditempati oleh $\mathrm{A}_{4}, \mathrm{~A}_{3}$, dan $A_{2}$ dengan pertimbangan bahwa siswa $A_{1}$ tidak bermasalah untuk mempelajari semua topik/materi yang dipelajari.

Untuk kelompok yang lain, pembagian ke dalam kelompok ahli sama dengan langkahlangkah di atas.

c. Membagikan materi/topik-topik kepada ahli. Siswa ahli mempelajari materi yang diberikan (dapat ditugaskan sebagai pekerjaan rumah), kemudian setiap kelompok ahli berkumpul pada sebuah meja.

d. Guru menunjuk seorang pemimpin diskusi untuk setiap kelompok yang bertugas sebagai moderator, menunjuk anggota kelompok yang mengangkat tangan, dan mengupayakan agar setiap orang berpartisipasi. Seluruh anggota kelompok mencatat seluruh poin yang didiskusikan. Ketika kelompok ahli berdiskusi, guru berkeliling kelas, bergantian mendatangi dan memfasilitasi setiap kelompok. Guru dapat menjawab pertanyaan dan mengatasinya bila ada salah pemahaman, namun tidak mengambil alih kepemimpinan.

e. Guru memberikan post-test kepada kelompok ahli untuk mengetahui pemahaman dan kesiapan masing-masing ahli untuk mengajarkan materi kepada timnya.

f. Para ahli kembali ke kelompok asal untuk mengajarkan materi itu kepada teman dalam kelompoknya. Perlu ditekankan kepada siswa bahwa mereka mempunyai tanggung jawab kepada teman satu kelompoknya, dan siap untuk menghadapi kuis individu yang diberikan guru.

g. Salah satu kelompok menyajikan hasil diskusi yang telah dilakukan agar guru dapat menyamakan persepsi pada materi pembelajaran yang telah didiskusikan.

h. Guru memberikan kuis untuk siswa secara individual.

i. Setiap kelompok mendapatkan penghargaan melalui skor penghargaan berdasarkan perolehan nilai peningkatan hasil belajar individual dari skor dasar ke skor kuis berikutnya.

\section{PEMBELAJARAN KONVENSIONAL}

Pembelajaran konvensional adalah suatu pembelajaran dimana proses belajar mengajar dilakukan dengan cara yang lama, yaitu dalam penyampaian pelajaran guru masih mengandalkan sistem ceramah. Di dalam pembelajaran matematika, pembelajaran konvensional yang paling sering dipakai adalah pendekatan ekspositori karena selain memberikan materi, 
guru juga memberikan soal-soal latihan untuk dikerjakan siswa.

Pembelajaran konvensional dalam pembelajaran matematika mempunyai banyak kelebihan dan kelemahan. Adapun kelebihan dan kelemahannya menurut Purwoto (2003: 67) adalah sebagai berikut:

Kelebihannya:

a. Dapat menampung kelas yang besar,

b. Bahan pelajaran/keterangan dapat diberikan secara lebih urut oleh guru, konsep-konsep yang disajikan secara hierarki akan memberikan fasilitas belajar bagi siswa.

c. Isi silabus dapat diselesaikan dengan lebih mudah, karena guru tidak harus menyesuaikan dengan kecepatan belajar siswa.

d. Kekurangan atau tidak adanya buku pelajaran dan alat bantu tidak menghambat dilaksanakannya pelajaran.

Kelemahannya:

a. Pelajaran berjalan membosankan siswa dan siswa menjadi pasif dan tidak berkembang.

b. Kepadatan konsep-konsep yang diberikan hanya akan membuat siswa tidak mampu menguasai materi pelajaran.

c. Pengetahuan yang didapat dari metode ini mudah terlupakan.

d. Ceramah menyebabkan belajar siswa menjadi 'belajar menghafal' yang tidak menyebabkan timbulnya pengertian.

\section{GAYA KOGNITIF}

Salah satu karakteristik siswa yang mempengaruhi hasil belajar adalah gaya kognitif.
Oleh karena itu gaya kognitif merupakan salah satu variabel kondisi belajar yang menjadi salah satu bahan pertimbangan dalam merangsang suatu pembelajaran di sekolah.

Menurut Keefe (1987:7) dalam Mohidin, gaya kognitif merupakan bagian gaya belajar yang menggambarkan kebiasaan berperilaku yang tetap dalam diri seseorang dalam menerima, memikirkan, memecahkan masalah maupun dalam menyimpan informasi. Seperti diungkapkan Messic et.al. (1976:26), gaya kognitif merupakan information processing habits representing the learners typical mode of perceiving, thinking, problem solving, and membering. Dengan kata lain gaya kognitif adalah kebiasaan bertindak yang relatif tetap dalam diri seseorang dalam cara berpikir, mengingat, menerima dan mengolah suatu informasi tentang obyek tertentu.

Gaya kognitif berkaitan erat dengan pribadi seseorang, yang tentu dipengaruhi oleh pendidikan dan riwayat perkembangannya. Ada tiga type gaya kognitif yang ada kaitannya dengan proses belajar mengajar (Witkin dalam Nasution, 2006:94). Yakni gaya kognitif menurut tipe: (1). field dependent - field dependent, (2) impulsif - reflektif, dan (3) preseptif / reseptif sistematis / intuitif.

Perbedaan-perbedaan kedua tipe tersebut menurut Nasution (2010:95) seperti dibawah ini: 
Tabel 2. Gaya Kognitif field dependent dan field independent.

\begin{tabular}{|c|c|}
\hline \multicolumn{2}{|c|}{ Gaya Kognitif } \\
\hline Field Dependent & Field Independent \\
\hline $\begin{array}{l}\text { 1. Sangat dipengaruhi oleh } \\
\text { lingkungan, banyak bergantung } \\
\text { pada pendidikan sewaktu kecil. }\end{array}$ & $\begin{array}{l}\text { 1. Kurang dipengaruhi oleh } \\
\text { lingkungan dan oleh pendidikan di } \\
\text { masa lampau. }\end{array}$ \\
\hline $\begin{array}{l}\text { 2. Mengingat hal-hal dalam konteks } \\
\text { sosial. }\end{array}$ & $\begin{array}{l}\text { 2. Tidak peduli akan norma orang } \\
\text { lain. }\end{array}$ \\
\hline $\begin{array}{l}\text { 3. Bicara lambat agar dapat dipahami } \\
\text { orang lain. }\end{array}$ & $\begin{array}{l}\text { 3. Berbicara cepat tanpa } \\
\text { menghiraukan daya tangkap orang } \\
\text { lain. }\end{array}$ \\
\hline $\begin{array}{l}\text { 4. Mempunyai hubungan sosial yang } \\
\text { luas. }\end{array}$ & $\begin{array}{l}\text { 4. Kurang mementingkan hubungan } \\
\text { sosial. }\end{array}$ \\
\hline $\begin{array}{l}\text { 5. Lebih cocok untuk memilih } \\
\text { psikologi klinis. }\end{array}$ & $\begin{array}{l}\text { 5. Lebih memilih psikologi } \\
\text { eksperimental. }\end{array}$ \\
\hline $\begin{array}{l}\text { 6. Lebih banyak terdapat dikalangan } \\
\text { wanita. }\end{array}$ & $\begin{array}{l}\text { 6. Banyak pria, namun banyak yang } \\
\text { overlapping. }\end{array}$ \\
\hline $\begin{array}{l}\text { 7. Tidak senang pelajaran } \\
\text { matematika, lebih menyukai bidang } \\
\text { humanitas dan ilmu-ilmu sosial. }\end{array}$ & $\begin{array}{l}\text { 7. Dapat menghargai humanitas dan } \\
\text { ilmu-ilmu sosial walaupun lebih } \\
\text { cenderung kepada matematika dan } \\
\text { ilmu pengetahuan alam. }\end{array}$ \\
\hline $\begin{array}{l}\text { 8. Memerlukan petunjuk lebih banyak } \\
\text { untuk memahami sesuatu, bahan } \\
\text { hendaknya tersusun langkah demi } \\
\text { langkah. }\end{array}$ & $\begin{array}{l}\text { 8. Tidak memerlukan petunjuk yang } \\
\text { terperinci. }\end{array}$ \\
\hline $\begin{array}{l}\text { 9. Lebih peka akan kritik dan perlu } \\
\text { mendapat dorongan, kritik jangan } \\
\text { bersifat pribadi. }\end{array}$ & $\begin{array}{l}\text { 9. Dapat menerima } \\
\text { perbaikan. }\end{array}$ \\
\hline
\end{tabular}

Untuk mengukur gaya kognitif siswa field dan $\mathrm{H}$ yang harus ditemukan pada ke-25 gambar independent dan field dependent, digunakan instrumen yang dikembangkan oleh Witkin (1971) yang disebut Group Embedded Figure Test (GEFT). GEFT merupakan tes standar yang memiliki skala tetap dengan skor 0 sampai 18 dimana setiap jawaban benar bernilai 1 dan jawaban salah bernilai 0 , sehingga penilaian yang dilakukan bersifat obyektif.

Instrumen ini terdiri dari 25 gambar rumit dan gambar sederhana yang terbagi menjadi tiga tahap. Tahap pertama terdiri dari 7 gambar, sedangkan tahap kedua dan ketiga masing-masing terdiri dari 9 gambar. Terdapat 8 gambar sederhana yang diberi nama A, B, C, D, E, F, G, pada soal dengan cara menebalkan gambar sederhana tersebut dalam gambar rumit.

Untuk tahap pertama, siswa diberi waktu untuk mengerjakan tes maksimal 3 menit. Hasil tes tahap pertama ini hanya digunakan untuk latihan dan tidak dinilai. Tahap kedua dan ketiga, siswa diberi waktu maksimal 6 menit untuk menyelesaikan soal dengan masing-masing jawaban benar diberi nilai 1 dan jawaban salah diberi nilai 0 . Siswa yang tidak dapat menyelesaikan gambar pada tes sesuai waktu yang ditentukan pada masing-masing tahapan, maka gambar yang tidak dikerjakan dianggap salah dan diberi nilai 0 . 
Pengelompokan gaya kognitif siswa dilakukan dengan penskoran sesuai kriteria. Menurut Kepner dan Neimark (1984), jika siswa mendapat nilai kurang dari 10 dikatakan mempunyai gaya kognitif field dependent ( $\mathrm{p}$. 1408). Jika siswa mendapat nilai 10 ke atas maka dikatakan mempunyai gaya kognitif field independent.

\section{METODE PENELITIAN}

Penelitian ini dilaksanakan di SMP Negeri di kabupaten Grobogan dengan subyek penelitian adalah siswa kelas VIII (delapan). Penelitian ini dilaksanakan pada semester genap tahun pelajaran 2010/2011 tepatnya pada bulan Pebruari sampai dengan Juni 2011.

Penelitian yang dilaksanakan merupakan penelitian eksperimental semu. Pada penelitian ini, Langkah yang diambil adalah cara mengusahakan timbulnya variabel-variabel dan selanjutnya dikontrol untuk dilihat pengaruhnya terhadap prestasi belajar matematika sebagai variabel terikat. Variabel bebas yang dimaksud adalah model pembelajaran yaitu model pembelajaran kooperatif tipe Jigsaw yang dimodifikasi, model pembelajaran kooperatif tipe Jigsaw, dan pembelajaran konvensional, sedangkan variabel bebas lain adalah gaya kognitif siswa. Pada akhir penelitian, ketiga kelompok diukur dengan menggunakan alat ukur yang sama yaitu soal-soal tes prestasi belajar matematika siswa. Hasil pengukuran tersebut dianalisis dan dibandingkan dengan tabel uji statistik yang digunakan.
Prosedur yang dilakukan dalam penelitian ini adalah:

a. Menentukan populasi;

b. Menentukan sampel secara stratified cluster random sampling, sampel dibagi menjadi tiga kelompok yaitu kelompok eksperimen 1 ,kelompok eksperimen 2 dan kelompok kontrol kemudian melakukan uji keseimbangan pada ketiga sampel tersebut untuk mengetahui apakah ketiganya dalam keadaan seimbang;

c. Melakukan pengambilan data tentang gaya belajar siswa dengan angket yang dikategorikan menjadi dua kategori kelompok siswa yaitu kelompok siswa dengan gaya kognitif field independent dan field dependent;

d. Kelompok eksperimen 1 diberikan pembelajaran dengan model kooperatif tipe Jigsaw yang dimodifikasi ,kelompok eksperimen 2 diberikan pembelajaran dengan model kooperatif tipe Jigsaw dan kelompok kontrol dengan pembelajaran konvensional;

e. Melakukan tes prestasi belajar matematika untuk pokok bahasan bangun ruang sisi datar;

f. Melakukan analisis data untuk mengetahui signifikansi perbedaan prestasi belajar siswa pada pokok bahasan bangun ruang sisi datar ditinjau dari penggunaan model pembelajaran yang berbeda, gaya kognitif dan interaksi model pembelajaran dan gaya kognitif.

Populasi penelitian ini adalah seluruh siswa kelas VIII SMP Negeri se-kabupaten Grobogan tahun 2010/2011 yang berjumlah 57 sekolah. Pengambilan sampel dilakukan secara acak kelompok bertingkat (stratified cluster 
random sampling) pada SMP Negeri se Kabupaten Grobogan. Pertama dilakukan pengelompokan sekolah berdasarkan rangking sekolah yang didasarkan pada jumlah nilai UN tahun pelajaran 2009/2010 menjadi 3 kelompok yaitu tinggi, sedang dan rendah. Selanjutnya dari masing-masing cluster (kelompok) dipilih secara acak, yaitu: SMP Negeri 1 Purwodadi sebagai SMP dengan kemampuan tinggi, SMP Negeri 2 Grobogan sebagai SMP dengan kemampuan sedang dan SMP Negeri 6 Purwodadi sebagai SMP dengan kemampuan rendah. Sebelum penelitian dilakukan, antara kelompok eksperimen 1, kelompok eksperimen 2 dan kelompok kontrol diuji dengan uji anava satu jalan dengan sel tak sama berdasarkan nilai ulangan semester ganjil kelas VIII SMP bidang studi matematika.

Pada penelitian ini, metode yang digunakan dalam pengambilan data adalah metode tes dan metode dokumentasi. Metode tes digunakan untuk mengetahui nilai prestasi belajar matematika siswa dan skor gaya kognitif siswa, serta metode dokumentasi digunakan untuk mengetahui kemampuan awal siswa. Sebelum digunakan untuk mengambil data dalam penelitian, instrumen tes diuji terlebih dahulu dengan uji validitas dan reliabilitas untuk mengetahui kualitas tiap item. Untuk instrumen tes, uji tersebut meliputi uji validitas isi, perhitungan daya beda dan indeks kesukaran serta uji reliabilitas.

Pada awal penelitian dilakukan uji prasyarat keseimbangan yaitu uji normalitas dan homogenitas nilai awal. Setelah semua prasyarat terpenuhi kemudian dilakukan uji keseimbangan dengan menggunakan uji anava satu jalan dengan sel tak sama. Selanjutnya pada nilai hasil penelitian dilakukan uji prasyarat analisis yang berupa uji normalitas dan uji homogenitas baru kemudian dilakukan uji hipotesis dengan analisis variansi dua jalan dengan sel tak sama. Setelah dilakukan uji hipotesis, bila perlu dilakukan juga uji lanjut pasca anava dengan melakukan uji komparasi ganda.

\section{HASIL PENELITIAN}

Data dalam penelitian ini meliputi data hasil uji coba instrumen, data prestasi belajar matematika siswa dan data gaya kognitif siswa. Tes prestasi belajar matematika berbentuk pilihan ganda yang terdiri dari 40 nomor dengan lima pilihan jawaban yaitu: a, b, c, dan d. Penilaian validitas isi dilakukan dengan menggunakan daftar check list $(\sqrt{ })$ yang dilakukan oleh Yadi Suyanto, S.Pd., guru matematika SMPN 1 Purwodadi yang sekaligus ketua MGMP matematika kabupaten Grobogan dan Sumarsih, M.Pd., guru matematika SMPN 6 Purwodadi yang sekaligus guru pemandu MGMP Matematika kabupaten Grobogan. Untuk nilai reliabilitas, suatu soal dapat digunakan jika nilai reliabilitasnya lebih dari atau sama dengan 0,7. Berdasarkan hasil perhitungan, diperoleh nilai reliabilitas 0,859 , maka soal dapat digunakan untuk melakukan tes.

Sedangkan untuk tingkat kesukaran (TK), suatu butir soal dapat digunakan jika nilai $0,3 \leq T K<0,7$. Jika nilai tingkat kesukaran 
kurang dari 0,3 maka soal termasuk kriteria terlalu sulit, dan jika nilai tingkat kesukaran lebih dari atau sama dengan 0,7 maka soal tersebut termasuk kriteria terlalu mudah. Berdasarkan hasil perhitungan, nilai tingkat kesukaran yang kurang dari 0,3 yaitu butir soal nomor 23, 26, 29, $32,34,36$, dan 28, maka butir-butir soal tersebut harus dibuang. Suatu butir soal dapat digunakan jika nilai daya pembeda lebih dari atau sama dengan 0,3. Berdasarkan hasil perhitungan, butir soal yang nilai daya pembedanya kurang dari 0,3 yaitu butir soal nomor 23, 26, 29, 32, 34, 36, dan 28. Sehingga dengan demikian butir-butir soal tersebut tidak dapat dipakai (harus dibuang).

Berdasar uraian di atas, maka butir soal yang dapat dipakai untuk melakukan tes adalah butir soal nomor $1,2,3,4,5,6,7,8,9,10,11$, $12,13,14,15,16,17,18,19,20,21,22,24,25$, 27, 28, 30, 31, 33, 35, 37, 39, 40. Untuk keperluan penelitian ini maka diambil sebanyak 30 butir soal yaitu butir soal nomor: 1, 2, 3, 4, 5, $6,7,8,9,10,12,13,14,15,16,17,19,20,21$, $22,24,25,27,28,30,31,33,35,37,40$. Soal nomor 11, 18, dan 39 tidak dipakai untuk tes prestasi.

Uji keseimbangan dilakukan untuk mengetahui apakah sampel mempunyai kemampuan awal sama. Sebelum diuji keseimbangan, masing-masing sampel terlebih dahulu diuji apakah berdistribusi normal atau tidak, serta diuji apakah sampel berasal dari populasi yang homogen atau tidak.

Hasil dari uji normalitas kemampuan awal kelas eksperimen dan kelas kontrol disajikan alam Tabel 3.

Berdasarkan Tabel 3, untuk masingmasing sampel nilai dari $\mathrm{L}_{\mathrm{obs}}<\mathrm{L}_{0,05 ; n}$, sehingga $\mathrm{H}_{0}$ diterima. Ini berarti bahwa masing-masing sampel berasal dari populasi yang berdistribusi normal.

Selain uji normalitas, dilakukan juga uji homogenitas nilai awal. Hasil dari uji homogenitas nilai awal kelas eksperimen dan kelas kontrol disajikan dalam Tabel 4.

Berdasarkan Tabel 4, harga dari $\chi_{\text {obs }}^{2}<\chi^{2}$ 0,05;2 sehingga dapat disimpulkan bahwa sampel berasal dari populasi yang homogen.

Tabel 3. Hasil Uji Normalitas Nilai Awal

\begin{tabular}{|l|l|l|l|l|}
\hline Kelompok & $\mathrm{L}_{\mathrm{obs}}$ & $\mathrm{L}_{0,05 ; \mathrm{n}}$ & Keputusan & Kesimpulan \\
\hline $\begin{array}{l}\text { Eksperimen 1 } \\
\text { (Jigsaw yang Dimodifikasi) }\end{array}$ & 0,0395 & 0,0873 & Ho diterima & Normal \\
\hline Eksperimen 2 (Jigsaw) & 0,0590 & 0,0869 & Ho diterima & Normal \\
\hline Konvensional & 0,0814 & 0.0886 & Ho diterima & Normal \\
\hline
\end{tabular}

Tabel 4. Hasil Uji Homogenitas Nilai Awal

\begin{tabular}{|l|l|l|l|l|l|}
\hline Sampel & $\mathrm{k}$ & $\chi_{\text {obs }}^{2}$ & $\chi_{0,05 ; 2}^{2}$ & Keputusan & Kesimpulan \\
\hline Kelas & 3 & 1,2709 & 5,9910 & $\mathrm{H}_{0}$ diterima & Homogen \\
\hline
\end{tabular}


Tabel 5. Rangkuman Analisis Variansi Dua Jalan dengan Sel Tak Sama

\begin{tabular}{|l|l|l|l|l|l|l|}
\hline Sumber & JK & DK & RK & $\mathrm{F}_{\text {obs }}$ & $\mathrm{F}_{\text {tabel }}$ & Keputusan \\
\hline A & 6681,064 & 2 & 3440,532 & 26,749 & 3,026 & $\mathrm{H}_{0}$ ditolak \\
\hline B & 2913,572 & 1 & 2913,572 & 22,652 & 3,873 & $\mathrm{H}_{0}$ ditolak \\
\hline AB & 416,175 & 2 & 208,088 & 1,618 & 3,026 & $\mathrm{H}_{0}$ diterima \\
\hline Galat & 38714,827 & 301 & 128,621 & & & \\
\hline Total & 48925,638 & 306 & & & & \\
\hline
\end{tabular}

Hasil perhitungan analisis variansi dua jalan sel tak sama dengan tingkat signifikansi 0,05 disajikan pada Tabel 5 .

Dari Tabel 6, tampak bahwa $\mathrm{H}_{0 \mathrm{~A}}$ ditolak karena nilai uji $\mathrm{F}_{\mathrm{a}}=26,749$ lebih besar dari $\mathrm{F}_{0,05 ; 2 ; 301}=3,026$. Hal ini berarti terdapat perbedaan rataan model pembelajaran Jigsaw yang dimodifikasi, Jigsaw dan konvensional terhadap prestasi belajar matematika. Dan $\mathrm{H}_{0 \mathrm{~B}}$ ditolak karena nilai uji $F_{b}=22,652$ lebih besar dari $\mathrm{F}_{0,05 ; 2 ; 301}=3,873$. Hal ini berarti terdapat pengaruh gaya kognitif siswa terhadap prestasi belajar matematika. Sedangkan $\mathrm{H}_{0 \mathrm{AB}}$ diterima karena nilai uji $\mathrm{F}_{\mathrm{ab}}=1,618$ lebih kecil dari $\mathrm{F}_{0,05 ; 4 ; 301}=3,026$. Hal ini berarti tidak terdapat interaksi antara model pembelajaran dengan gaya kognitif terhadap prestasi belajar matematika.

\section{Uji Lanjut Pasca Anava}

Setelah diperoleh hasil anava, langkah selanjutnya adalah uji lanjut pasca anava. Uji lanjut pasca anava perlu dilakukan untuk melihat manakah yang secara signifikan memberikan rataan yang berbeda sebagaimana Tabel 6 .

Dari rangkuman analisis variansi dua jalan dengan sel tak sama di atas telah diperoleh bahwa :

a. $\mathrm{H}_{0 \mathrm{~A}}$ ditolak, maka perlu dilakukan uji komparasi ganda.

Rangkuman uji komparasi ganda dengan metode Scheffe' disajikan dalam Tabel 7.

Tabel 6. Rerata Skor Prestasi Belajar Siswa

\begin{tabular}{|c|c|c|c|c|}
\hline \multirow{2}{*}{\multicolumn{2}{|c|}{$\mathrm{B}$}} & \multicolumn{2}{|c|}{ Gaya Kognitif Siswa } & \multirow{2}{*}{$\begin{array}{l}\text { Rataan } \\
\text { Marginal }\end{array}$} \\
\hline & & $\mathrm{B}_{1}$ & $\mathrm{~B}_{2}$ & \\
\hline \multirow{3}{*}{$\begin{array}{l}\text { Model } \\
\text { Pembelajaran }\end{array}$} & $A_{x}$ & 77,3913 & 72,5250 & 73,6117 \\
\hline & $\mathrm{A}_{2}$ & 73,4211 & 61,6588 & 63,8077 \\
\hline & $\mathrm{A}_{3}$ & 63,6842 & 57,0741 & 58,3300 \\
\hline \multicolumn{2}{|c|}{ Rataan Marginal } & 71,8852 & 63,6829 & \\
\hline
\end{tabular}


Tabel 7. Hasil Uji Komparasi Ganda Antar Baris

\begin{tabular}{|l|l|l|l|}
\hline $\mathrm{H}_{0}$ & $\mathrm{~F}_{\mathrm{obs}}$ & $2 \mathrm{~F}_{(0,05 ; 2 ; 301)}$ & Keputusan \\
\hline$\mu_{1 \bullet}=\mu_{2 \bullet}$ & 38,6716 & 6,0520 & $\mathrm{H}_{0}$ ditolak \\
\hline$\mu_{1 \bullet}=\mu_{3 \bullet}$ & 92,1236 & 6,0520 & $\mathrm{H}_{0}$ ditolak \\
\hline$\mu_{2 \bullet}=\mu_{3 \bullet}$ & 11,8929 & 6,0520 & $\mathrm{H}_{0}$ ditolak \\
\hline
\end{tabular}

b. $\mathrm{H}_{0 \mathrm{~B}}$ ditolak.

Karena variabel gaya kognitif hanya mempunyai dua kategori yaitu field independent dan field dependent, maka untuk antar kolom tidak perlu dilakukan komparasi ganda tetapi hanya melihat pada rerata marginalnya.

c. $\mathrm{H}_{0 \mathrm{AB}}$ diterima

Berarti tidak terdapat interaksi yang antara model pembelajaran dan gaya belajar siswa, maka tidak perlu dilakukan uji komparasi ganda.

\section{KESIMPULAN}

Berdasarkan hasil penelitian dan pembahasan dapat disimpulkan bahwa pada siswa kelas VIII (delapan) SMP Negeri di Kabupaten Grobogan, khususnya pada materi bangun ruang sisi datar:

1. Model pembelajaran kooperatif tipe Jigsaw yang dimodifikasi memberikan prestasi belajar yang lebih baik dibandingkan dengan model pembelajaran kooperatif tipe Jigsaw dan keduanya lebih baik daripada pembelajaran konvensional pada materi bangun ruang sisi datar.
2. Siswa dengan gaya kognitif field independent memiliki prestasi belajar yang lebih baik dibanding siswa dengan gaya kognitif field dependent.

3. Pada siswa dengan gaya kognitif field independent maupun field dependent yang diberikan model pembelajaran kooperatif tipe Jigsaw yang dimodifikasi mempunyai prestasi belajar lebih baik dibandingkan model pembelajaran kooperatif tipe Jigsaw dan keduanya lebih baik daripada pembelajaran konvensional pada materi bangun ruang sisi datar.

\section{IMPLIKASI}

Berdasarkan pada kajian teori dan mengacu pada hasil penelitian ini, penulis akan menyampaikan implikasi yang bermanfaat baik secara teoritis maupun praktis dalam upaya meningkatkan prestasi belajar matematika.

1. Implikasi teoritis

Hasil penelitian menunjukkan bahwa model pembelajaran kooperatif tipe Jigsaw yang dimodifikasi memberikan prestasi belajar yang lebih baik dibanding yang menggunakan model pembelajaran kooperatif tipe Jigsaw dan keduanya lebih baik daripada 
pembelajaran konvensional. Sehingga model pembelajaran Jigsaw yang dimodifikasi dapat diterapkan pada proses belajar mengajar di kelas sebagai upaya meningkatkan prestasi belajar matematika siswa. Selain pendekatan pembelajaran, penelitian ini juga berkaitan dengan gaya kognitif siswa. Dari penelitian diketahui bahwa prestasi belajar matematika siswa terkait dengan gaya kognitif yang mereka miliki. Siswa yang mempunyai gaya kognitif field independent akan memiliki prestasi belajar yang lebih baik dibandingkan dengan siswa yang memiliki gaya kognitif field dependent, baik diberikan model pembelajaran kooperatif tipe Jigsaw yang dimodifikasi, tipe Jigsaw, maupun konvensional.

\section{Implikasi Praktis}

Berdasarkan kesimpulan di atas dapat dikemukakan bahwa pembelajaran materi bangun ruang sisi datar dengan menggunakan model pembelajaran kooperatif tipe Jigsaw yang dimodifikasi menghasilkan prestasi belajar matematika yang lebih baik dibandingkan dengan yang menggunakan model pembelajaran kooperatif tipe Jigsaw maupun pembelajaran konvensional dan model pembelajaran kooperatif tipe Jigsaw memberikan prestasi lebih baik dibandingkan pembelajaran konvensional. Sehingga secara praktis, model pembelajaran kooperatif tipe Jigsaw yang dimodifikasi dapat digunakan sebagai alternatif para guru matematika untuk membelajarkan materi tersebut dalam upaya meningkatkan prestasi belajar siswa.
Disamping itu guru juga perlu memperhatikan gaya kognitif siswa, karena dari hasil penelitian ternyata gaya kognitif juga berpengaruh terhadap prestasi belajar siswa.

\section{SARAN}

Berdasarkan kesimpulan dan implikasi penelitian di atas, maka dapat dikemukakan saran sebagai berikut:

1. Kepada para Kepala Sekolah

a. Hendaknya kepala sekolah menyarankan kepada guru matematika agar dalam memberikan pembelajaran dapat memperoleh hasil yang maksimal harus memilih model pembelajaran yang sesuai dengan gaya kognitif siswa, salah satu model yang dapat diterapkan dalam pembelajaran di sekolah diantaranya adalah model pembelajaran kooperatif tipe Jigsaw yang dimodifikasi dan tipe Jigsaw.

b. Agar proses pembelajaran matematika dengan menggunakan model pembelajaran kooperatif tipe Jigsaw yang dimodifikasi dan tipe Jigsaw dapat berjalan dengan baik dan menghasilkan prestasi belajar yang maksimal, sebaiknya kepala sekolah menyediakan kelas dengan tempat duduk dan meja yang sudah diatur untuk keperluan diskusi, sehingga setiap proses pembelajaran matematika akan berlangsung tidak perlu mengatur tempat duduk dan meja, dan jika proses pembelajaran sudah selesai tidak mengembalikan tempat duduk dan meja karena akan memakan waktu dan menimbulkan suara dan gaduh. 
c. Sebaiknya kepala sekolah menyediakan sarana dan prasarana yang dibutuhkan dalam pembelajaran matematika dengan model pembelajaran kooperatif tipe Jigsaw yang dimodifikasi dan tipe Jigsaw agar pelaksanaannya dapat berjalan dengan baik sehingga memperoleh prestasi belajar yang maksimal.

2. Kepada para guru matematika

a. Dalam menerapkan model pembelajaran kooperatif tipe Jigsaw yang dimodifikasi dan tipe Jigsaw harus memperhatikan tingkat heterogenitas masing-masing kelompok asal, dan pemberian tugas kepada siswa yang akan menjadi tim ahli sesuai dengan kemampuan siswa.

b. Dalam pembelajaran matematika, guru hendaknya memperhatikan perbedaan gaya kognitif siswa diantaranya gaya kognitif field independent dan field dependent, karena gaya kognitif mempengaruhi prestasi belajar siswa sehingga dapat memilih model pembelajaran yang tepat untuk digunakan.

3. Kepada para siswa

a. Sebaiknya siswa selalu memperhatikan dengan sungguh-sungguh penjelasan guru tentang tata cara penggunaan model pembelajaran yang akan digunakan dan memahami dengan baik materi pelajaran yang dijelaskan oleh teman-temannya, baik pada kelompok ahli maupun kelompok asal.

b. Sebaiknya siswa mengikuti dengan aktif jalannya diskusi, selalu memperhatikan dan menghargai penjelasan, pendapat, pertanyaan atau jawaban yang disampaikan oleh siswa lain pada saat diskusi, baik pada kelompok asal maupun kelompok ahli.

4. Kepada peneliti lain

Bagi para peneliti diharapkan untuk dapat mengembangkan penelitian ini dengan penelitian-penelitian sejenis pada materi pelajaran yang lain agar penelitian ini dapat dimanfaatkan secara luas. Selain itu juga dapat diteliti pembelajaran kooperatif dengan tinjauan lain, misalnya kemandirian belajar siswa.

\section{DAFTAR PUSTAKA}

Abdul Djabar Mohidin. Pengaruh Bentuk Tes dan Gaya Kognitif Siswa Terhadap Validitas Tes Matematika SMA seKabupaten Gorontalo. Tesis. Tidak diterbitkan.

Anas Sudijono. 2009. Pengantar Evaluasi Pendidikan. Jakarta. PT Raja Grafindo Persada.

Anita Lie. 2005. Cooperative Learning Mempraktikkan Cooperative Learning di Ruang-Ruang Kelas. Jakarta: Grasindo

Arends, R. 2008. Learning to Teach. Belajar untuk Mengajar. Translated by Soetjipto, HP. 2008. Yogyakarta : Pustaka Pelajar.

Asri Budiningsih, 2008. Belajar dan Pembelajaran. Jakarta: Rineka Cipta. 
Budiyono. 2003. Metodologi Penelitian

Pendidikan. Surakarta: Sebelas Maret University Press.

. 2009. Statistika Untuk Penelitian.

Surakarta: Sebelas Maret University

Press.

Chan Kam-wing. 2004. Using 'Jigsaw II' in

Teacher Education Programmes. Hong

Kong Teachers' Centre Journal. Vol.

3.

Cholik, dkk. 2007. Matematika untuk SMP Kelas

VIII Semester 2. Jakarta : Erlangga.

Depdiknas. 2006. Standar Isi. Jakarta.

Dimyati dan Mujiyono, 2009. Belajar dan

Pembelajaran. Jakarta: Depdikbud.

Durmus Kilic. 2008. The Effect of the Jigsaw

Technique on Learning the Concepts

of the Principles and Methods of

Teaching. World Applied Sciences

Journal 4 (supple 1): 109-114.

Farida Yusuf Tayibnapis, 2008. Evaluasi

Program dan Instrumen Evaluasi untuk Program Pendidikan dan

Penelitian. Jakarta: Rineka Cipta.

Guisande M. Adelina, et al. 2007. Field Dependence-Independence (FDI) Cognitive Style: An Analysis of Attentional Functioning. Psicothema 2007. Vol. 19, No 4. Pp. 572-577.

Hamzah B.Uno, 2007. Model Pembelajaran.

Jakarta: Bumi Aksara.

H.A. Witkin, P.K. Oltman, E. Raskin and S.A. Karp. 1971. Group Embedded Figure Test. Palo Alto. CA: Consulting Psychologists Press, Inc.
H.A. Witkin, C.A. Moore, D.R. Goodenough and P.W. Cox. 1977. Field-dependent and Field-independent Cognitive style and their Educational Implications. Review of Educational Research 47. pp. 1 64.

Isjoni. 2009. Pembelajaran Kooperatif meningkatkan Kecerdasan

Komunikasi Antar Peserta Didik.

Yogyakarta: Pustaka Pelajar. . 2007. Cooperative Learning. Bandung:

Alfabeta.

Jailani Md. Yunos, Wan Mohd Rashid Wan Ahmad, Ahmad Rizal Madar. 2007. Field Dependence-Independence Students and Animation Graphic Courseware Based Instruction. MEDC Volume 1, Desember 2007. Faculty of Technical Education, Universiti Tun Hussein Onn Malaysia.

John Brenner. 1997. An Analysis of Students' Kognitif Style in Asyncronous Distance Education Courses. From Inquiry, Volume 1, Number 1, Spring 1997, 37-44.

Joyce, Bruce. Marsha Weil \& Emily Calhoun. 2000. Models of Teaching. Boston: Allyn and Bacon.

Kepner, MD, \& Neimark, ED. 1984. Test-retest Reliability and Differensial Pattern of Score Change on the Group Embedded Figures Test. Journal of Personality and Social Psychology, 46 (6), 1405-1413. 
Marhadi Saputro. 2011. Analisis kemampuan Pemecahan Masalah Matematika berdasarkan Langkah-langkah Polya ditinjau dari Gaya Kognitif Siswa. Tesis. Tidak diterbitkan. Surakarta. PPS UNS.

Marjohan. 2007. Tinggalkan Metode Konvensional.

http://enewsletterdisdik.wordpress.co m/2007/11/09/opini-tinggalkanlahmetode-konvensional/ diakses pada tanggal 28 Pebruari 2011.

Messick, et al (eds). Individuality in Learning. San Fransisco. CA: Jossey-Bass (1976) pp. $38-72$.

Moh. Amien. 2005. Pemetaan Konsep Suatu Teknik untuk Meningkatkan Hasil Belajar yang Bermakna. Yogyakarta. FPMIPA-IKIP.

Muhibbin Syah. 2005. Psikologi Pendidikan. Bandung : Remaja Rosdakarya.

Nasution. 2010. Berbagai Pendekatan dalam Proses Belajar Mengajar. Jakarta: Bumi Aksara.

Nazanin Nilforooshan dan Akbar Afghari. 2007. The Effect of Field DependenceIndependence as a Source of Variation in EFL Learners Writing Performance. Iranian Journal of Language Studies (IJLS). Vol. 1(2), 2007 (pp. 103-118).

Oemar Hamalik. 2008. Proses Belajar Mengajar. Jakarta: Bumi Aksara.

2009. Kurikulum dan

Pembelajaran. Jakarta: Bumi Aksara.
PPPPTK. 2009. Limas. Yogyakarta. Edisi Nomor 22, April 2009.

Purwoto. 2003. Strategi Pembelajaran Matematika. Surakarta: UNS Press.

Pusat Penilaian Pendidikan - Balitbang. 2009. Jakarta. Depdiknas.

Jakarta. Depdiknas.

Ratumanan, T.G. 2001. Pengaruh Model Pembelajaran dan Gaya Kognitif terhadap Hasil Belajar Matematika Siswa SMP Negeri 1dan SMP Negeri 4 Ambon. Proposal Disertasi. Tidak diterbitkan. Surabaya. PPS Unesa.

Sanjaya dan Wina. 2008. Strategi Pembelajaran. Jakarta. Kencana Prenada Media Group

Seth Sulaiman dan Low Fee Ngoo. 2008. Corak Gaya Kognitif dan Tahap Penguasaan Konsep Daya Newtonian di kalangan Pelajar Tingkatan Enam Rendah: Satu Kajian Rintis. Seminar Kebangsaan Pendidikan Sains dan Matematik. Persatuan Pendidikan Sains Dan Matematik Johor, Fakulti Pendidikan, Universiti Teknologi Malaysia \& Jabatan Pendidikan Negeri Johor.

S.M Shofiah. 2007. Pembelajaran Matematika Melalui Pendekatan Konstruktivisme dalam Upaya Meningkatkan Kemampuan Penalaran Induktif Siswa. Tidak diterbitkan.

Slameto. 2010. Belajar dan Faktor-faktor yang Mempengaruhi. Jakarta: Rineka Cipta. 
Sugiyono. 2010. Metode Penelitian Kuantitatif, Kualitatif dan $R$ \& $D$. Bandung: Alfabeta.

Suharsimi Arikunto. 1998. Prosedur Penelitian. Jakarta: Rineka Cipta.

Suradi. 2007. Studi Eksplorasi Gaya Pikir Siswa SMP tipe FI-FD Dikaitkan dengan kemampuan Menyelesaikan Sistem Persamaan Linier Dua Variabel. Jurnal Pendidikan Dasar, Vol. 8 no. 1, Maret 2007.

Suryanto. 2007. Cooperatif Learning. Jogjakarta. Thompson, M.E dan Thompson, M.E. 1987. Field Dependence-Independence And Learning From Instructional Text. Annual convention of the association for educational communications and technology. Februari 26 - Mac 1. Atlanta, GA. 733 - 744.

Xiao Mengduo dan Jin Xiaoling. 2010. Jigsaw Strategy as a Cooperative Learning Technique: Focusing on the Language Learners. Chinese Journal of Applied Linguistics (Bimonthly). Vol. 33 No. 4. Aug. 2010.

Yatim Riyanto. 2009. Paradigma Baru Pembelajaran. Jakarta: Kencana Prenada Media Grup. 